\title{
Assessment of platelet function during transcatheter aortic valve implantation
}

\section{(D)Zvonimir Ostojić*, DJure Samardžić, DSaša Pavasović, DDubravka Šipuš, Divica Šafradin, (D) Vlatka Rešković Lukšić, \\ (D)Jadranka Šeparović Hanževački, \\ (DBoško Skorić, \\ (DDavor Miličić, \\ (D)Joško Bulum}

University of Zagreb School of Medicine, University Hospital Centre Zagreb, Zagreb, Croatia
KEYWORDS: aortic stenosis, transcatheter aortic valve implantation, platelet reactivity, antiplatelet therapy CITATION: Cardiol Croat. 2020;15(3-4):59. | https://doi.org/10.15836/ccar2020.59

*ADDRESS FOR CORRESPONDENCE: Zvonimir Ostojić, KBC Zagreb, Kišpaticeva 12, HR-10000 Zagreb, Croatia. / Phone: +385-91-8980-702 / E-mail: ostojiczvonimir@gmail.com

ORCID: Zvonimir Ostojić, https://orcid.org/0000-0003-1762-9270 • Jure Samardzic, https://orcid.org/0000-0002-9346-6402 Saša Pavasović, https://orcid.org/0000-0002-3705-0226 • Dubravka Šipuš, https://orcid.org/0000-0002-5631-0353

Ivica Šafradin, https://orcid.org/0000-0003-4519-5940 • Vlatka Rešković Lukšić, https://orcid.org/0000-0002-4721-3236 Jadranka Šeparovic Hanževački, https://orcid.org/0000-0002-3437-6407 • Boško Skorić, https://orcid.org/0000-0001-5979-2346 Davor Miličić, https://orcid.org/0000-0001-9101-1570 • Joško Bulum, https://orcid.org/0000-0002-1482-6503

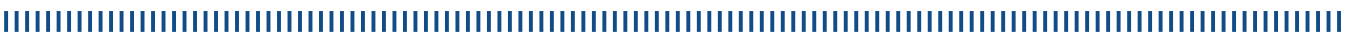

Introduction: Recent studies described changes in platelet reactivity (PR) in days following transcatheter aortic valve implantation (TAVI). ${ }^{1}$ However, precise time course and duration of these changes have not been fully investigated. Aim of the study was to investigate PR changes during and after TAVI

Patients and Methods: Study included 40 consecutive patients with severe and symptomatic aortic stenosis undergoing transfemoral TAVI procedure. Patients' clinical characteristics were collected from medical records. All patients who did not have chronic dual antiplatelet therapy received loading dose of aspirin and clopidogrel (300 mg) one day before the procedure followed by their standard maintenance doses. PR was measured in seven time points: before start of procedure (T1), after heparin administration (T2), 10 minutes after valve implantation (T3), at the end of procedure (T4), and on $3^{\text {rd }}, 6^{\text {th }}$ and $30^{\text {th }}$ postoperative day (T5-7). PR was measured using impedance aggregometer in response to three platelet aggregation agonists using ASPI, ADP and TRAP test.

Results: Mean patient age was 82.7 years with majority of patients being male $60 \%(\mathrm{~N}=25)$. All patients underwent successful transfemoral TAVI procedure using either self-expandable $(\mathrm{N}=25,62.5 \%)$ or balloon-expandable valve. Mean postimplantation gradient was $9.97 \pm 4.44 \mathrm{mmHg}$. More than mild paravalvular regurgitation persisted in $2(5 \%)$ patients. Values of PR in each tested time point are presented in Table 1. There was no significant difference in PR between T1 and T2. After the valve implantation significant reduction of PR in all 3 tests was observed. PR continued to decline on consecutive measurements, with lowest values reached on $3^{\text {rd }}$ post-TAVI day (T5). On T6, value of ASPI test were not significantly different to the ones measured on T1, while values of ADP and TRAP test remained significantly lower. By $30^{\text {th }}$ post-TAVI day PR values reached levels not significantly different compared to T1.

TABLE 1. Results of platelet reactivity test using ASPI, ADP and TRAP test in tested time points.

\begin{tabular}{|c|c|c|c|c|c|c|c|c|}
\hline & T1 & T2 & T3 & T4 & T5 & T6 & T7 & $\mathbf{P}$ \\
\hline ASPI & $22.97 \pm 23.01$ & $19.17 \pm 19.61$ & $10.36 \pm 11.60$ & $10.23 \pm 11.38$ & $9.71 \pm 10.68$ & $15.28 \pm 17.32$ & $20.97 \pm 21.26$ & $<0.001$ \\
\hline ADP & $40.46 \pm 23.68$ & $33.11 \pm 20.45$ & $24.15 \pm 14.07$ & $22.18 \pm 12.63$ & $14.95 \pm 8.59$ & $27.81 \pm 17.96$ & $33.11 \pm 23.60$ & $<0.001$ \\
\hline TRAP & $91.69 \pm 32.50$ & $93.42 \pm 27.71$ & $69.31 \pm 26.57$ & $64.05 \pm 24.20$ & $40.97 \pm 17.71$ & $69.09 \pm 29.08$ & $88.06 \pm 35.51$ & $<0.001$ \\
\hline
\end{tabular}

RECEIVED:

February 18, 2020

ACCEPTED:

February 22, 2020

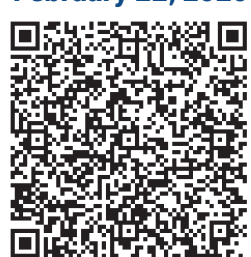

Conclusions: Presented results indicate that transfemoral TAVI induces transient decrease in PR regardless of the platelet activation pathway. Significant reduction of PR is observed 10 minutes after valve implantation with continuous decrease until 3rd day post-TAVI after which it is gradually increasing to pre-TAVI values.

LITERATURE IIIIIIIIIIIIIIIIIIIIIIIIIIIIIIIIIIIIIIIIIIIIIIIIIIIIIIIIIIIIIIIIIIIIIIIIIIIIIIIIIIIIIIIIIIIIIIIIIIIIIII

1. Orvin K, Eisen A, PerI L, Zemer-Wassercug N, Codner P, Assali A, et al. Platelet reactivity in patients undergoing transcatheter aortic valve implantation. J Thromb Thrombolysis. 2016 Jul;42(1):11-8. https://doi.org/10.1007/s11239-015-1322-3 